\title{
Molecular characterization of a conserved archaeal copper resistance (cop) gene cluster and its copper-responsive regulator in Sulfolobus solfataricus P2
}

\author{
Thijs J. G. Ettema,† Arie B. Brinkman, $\ddagger$ Packo P. Lamers, Noor G. Kornet, \\ Willem M. de Vos and John van der Oost

\begin{abstract}
Laboratory of Microbiology, Wageningen University, Hesselink van Suchtelenweg 4, 6703 CT Wageningen, The Netherlands
\end{abstract}

Correspondence

Thijs J.G. Ettema

T.Ettema@cmbi.ru.nl

Received 28 November 2005

Revised 20 March 2006

Accepted 27 March 2006

\begin{abstract}
Using a comparative genomics approach, a copper resistance gene cluster has been identified in multiple archaeal genomes. The cop cluster is predicted to encode a metallochaperone (CopM), a P-type copper-exporting ATPase (CopA) and a novel, archaea-specific transcriptional regulator (CopT) which might control the expression of the cop genes. Sequence analysis revealed that CopT has an N-terminal DNA-binding helix-turn-helix domain and a C-terminal TRASH domain; TRASH is a novel domain which has recently been proposed to be uniquely involved in metal-binding in sensors, transporters and trafficking proteins in prokaryotes. The present study describes the molecular characterization of the cop gene cluster in the thermoacidophilic crenarchaeon Sulfolobus solfataricus. The polycistronic copMA transcript was found to accumulate in response to growth-inhibiting copper concentrations, whereas cop $T$ transcript abundance appeared to be constitutive. DNA-binding assays revealed that CopT binds to the copMA promoter at multiple sites, both upstream and downstream of the predicted TATA-BRE site. Copper was found to specifically modulate the affinity of DNA binding by CopT. This study describes a copper-responsive operon in archaea, a new family of archaeal DNA-binding proteins, and supports the idea that this domain plays a prominent role in the archaeal copper response. A model is proposed for copper-responsive transcriptional regulation of the copMA gene cluster.
\end{abstract}

\section{INTRODUCTION}

Metal ions play an essential role as trace elements in many biological systems; current estimates indicate that over half of all proteins are metalloproteins, containing metal ions either as a structural component or as a catalytic co-factor (Degtyarenko, 2000). However, at higher concentrations heavy metal ions form aspecific complexes in the cell, leading to toxic effects. Some heavy metal cations, like $\mathrm{Hg}^{2+}, \mathrm{Cd}^{2+}$ and $\mathrm{Ag}^{+}$, form strong toxic complexes, which makes them unsuitable for physiological function. Also, essential trace elements like $\mathrm{Zn}^{2+}$ or $\mathrm{Ni}^{2+}$, and especially $\mathrm{Cu}^{2+}$, are toxic at elevated concentrations (Nies, 1999).

tPresent address: Centre for Molecular and Biomolecular Informatics, Nijmegen Centre for Molecular Life Sciences, UMC St Radboud, Toernooiveld 1, 6525 ED Nijmegen, The Netherlands.

$\ddagger$ Present address: Department of Molecular Biology, Nijmegen Centre for Molecular Life Sciences, UMC St Radboud, Geert Grooteplein 30, 6525 GA Nijmegen, The Netherlands.

Abbreviations: EMSA, electrophoretic mobility shift assay; HMA, heavymetal-associated domain; HTH, helix-turn-helix; TBP, TATA-boxbinding protein; TFB, transcription factor $\mathrm{B}$.
Both eukaryotes and prokaryotes have evolved several mechanisms that prevent the cell from being intoxicated by these metals. These homeostasis mechanisms include (i) sequestering of metals by metallothioneins (Blindauer et al., 2002; Camakaris et al., 1999), (ii) the efflux of metals by P-type cation-transporting ATPases (CTAs) (Lutsenko \& Kaplan, 1996), and (iii) trafficking of metal ions by metallochaperones (Harrison et al., 2000; Rosenzweig, 2002).

Metal homeostasis has been well studied in bacteria and eukaryotes. In humans, several diseases have been linked to an impaired metal balance, like the Menkes and Wilson's copper storage diseases (Mercer, 2001). In bacteria, several regulatory mechanisms have been identified that ensure a tight regulation of the expression of genes encoding metal homeostasis components. These mechanisms include twocomponent regulatory systems and metalloregulators. In general, the latter class of proteins comprise a DNA-binding domain and a metal-sensing domain. Examples of bacterial families of metalloregulators are the SmtB/ArsR transcriptional repressors (Busenlehner et al., 2003), the DtxR/MntR family (Guedon \& Helmann, 2003) and the MerR family (Brown et al., 2003). These metalloregulatory proteins 
have been found to display distinct metal selectivity profiles, generating a metal-specific transcriptional response (Busenlehner et al., 2003; Cavet et al., 2003; Guedon \& Helmann, 2003). Despite the fact that several archaeal species are able to thrive in environments that contain extremely high metal concentrations (Edwards et al., 2000), information about heavy metal resistance in these organisms is rather limited (Baker-Austin et al., 2005; Dixit et al., 2004; Mana-Capelli et al., 2003; Schelert et al., 2004).

The basal transcription machinery of archaea resembles that of eukaryotes. However, their transcriptional regulatory mechanisms appear to be different. Although a few homologues of eukaryote-like regulators are encoded by archaeal genomes, many potential bacterial-type transcriptional regulators have been identified (Aravind \& Koonin, 1999). Apparently, control of the eukaryotic-like transcription machinery in archaea mainly proceeds via bacterial-like regulators. Several studies have revealed that most of these archaeal transcriptional regulators act as repressors of transcription (see Bell, 2005, and references therein). Remarkably, recent studies have also provided evidence of positive control by these regulators (Brinkman et al., 2002; Ouhammouch et al., 2003). In addition to bacterial-like regulators, archaea appear to contain archaea-specific regulators (Gregor \& Pfeifer, 2001; Hochheimer et al., 1999).

Recently, we have identified a conserved archaeal gene cluster that comprises a potential copper resistance (cop) gene cluster (Ettema et al., 2003). Besides an archaea-specific transcription regulator $(\operatorname{cop} T)$, the cluster consists of genes encoding a putative metallochaperone ( $\operatorname{cop} M)$ and a P-type cation-transporting ATPase ( $\operatorname{copA}$ ). Interestingly, the CopT, CopM and CopA proteins encoded by the cop gene cluster contain a conserved cysteine signature (TRASH domain), implied to play a prominent role in archaeal metal resistance (Ettema et al., 2003). In the present study we have investigated the cop gene cluster of the thermoacidophilic crenarchaeon Sulfolobus solfataricus to elucidate its molecular function. The genes encoding CopM and CopA were found to be specifically induced upon exposure to copper and, to a lesser extent, upon exposure to cadmium. Furthermore, recombinantly produced CopT protein was found to bind the promoter region of the copMA operon in a copperdependent manner, indicating that CopT is a novel-type archaeal copper-responsive transcriptional regulator of the cop cluster.

\section{METHODS}

Multiple alignment of archaeal CopT homologues. All protein sequences were retrieved from the Entrez database (NCBI). A multiple alignment of archaeal CopT protein sequences was constructed using the CLUSTALX program (Thompson et al., 1994), followed by manual adjustment for conserved motifs based on BLAST results. Domain analysis of $S$. solfataricus CopT was performed using SMART (Letunic et al., 2004).

Growth of S. solfataricus. S. solfataricus P2 (DSM1617) was grown aerobically in baffled $250 \mathrm{ml}$ Erlenmeyer flasks filled with
$100 \mathrm{ml}$ chemically defined medium containing $\left(1^{-1}\right) 3 \cdot 1 \mathrm{~g} \mathrm{KH}_{2} \mathrm{PO}_{4}$,

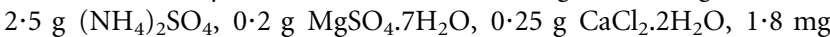
$\mathrm{MnCl}_{2} .4 \mathrm{H}_{2} \mathrm{O}, 4.5 \mathrm{mg} \quad \mathrm{Na}_{2} \mathrm{~B}_{4} \mathrm{O}_{7} .10 \mathrm{H}_{2} \mathrm{O}, 0.22 \mathrm{mg} \mathrm{ZnSO}_{4} .7 \mathrm{H}_{2} \mathrm{O}$, $0.06 \mathrm{mg} \mathrm{CuCl}_{2}, 0.03 \mathrm{mg} \mathrm{Na} \mathrm{MoO}_{4} .2 \mathrm{H}_{2} \mathrm{O}, 0.03 \mathrm{mg} \mathrm{VOSO}_{4} .2 \mathrm{H}_{2} \mathrm{O}$ and $0.01 \mathrm{mg} \mathrm{CoCl}_{2}$, supplemented with $0.02 \mathrm{~g} \mathrm{FeCl}_{3}$ and Wollin vitamins. The Wollin vitamin stock $(100 \times)$ contained $\left(1^{-1}\right) 2 \mathrm{mg}$ D-biotin, $2 \mathrm{mg}$ folic acid, $10 \mathrm{mg}$ pyridoxine- $\mathrm{HCl}, 10 \mathrm{mg}$ riboflavin, $5 \mathrm{mg}$ thiamine- $\mathrm{HCl}, 5 \mathrm{mg}$ nicotinic acid, $5 \mathrm{mg}$ DL-Ca-pantothenate, $0.1 \mathrm{mg}$ vitamin $\mathrm{B} 12,5 \mathrm{mg}$-aminobenzoic acid and $5 \mathrm{mg}$ lipoic acid. The medium was adjusted at room temperature to $\mathrm{pH} 3.5$ with $\mathrm{H}_{2} \mathrm{SO}_{4}$. After addition of sucrose as carbon source to a final concentration of $0.4 \%(\mathrm{w} / \mathrm{v})$ and subsequent inoculation, the culture was propagated at $80{ }^{\circ} \mathrm{C}$ in a rotary shaker at 130 r.p.m. Growth was monitored by measuring the optical density at $600 \mathrm{~nm}$.

For determination of the sensitivity of $S$. solfataricus towards various metals, different concentrations of metal salts $\left(\mathrm{CuSO}_{4}, \mathrm{Ag}_{2} \mathrm{SO}_{4}, \mathrm{CdCl}_{2}\right.$, $\mathrm{ZnSO}_{4}$ and $\mathrm{NiSO}_{4}$ ), as well as EDTA were added to an exponentially growing $S$. solfataricus culture $\left(100 \mathrm{ml}\right.$ culture, $\left.\mathrm{OD}_{600} \sim 0 \cdot 3-0 \cdot 4\right)$. The MICs for these compounds were defined as the concentration at which no further growth was observed for a period of $4 \mathrm{~h}$ by measuring the optical density at $600 \mathrm{~nm}$.

RNA isolation from $S$. solfataricus and primer extension analysis. S. solfataricus total RNA was isolated from mid-exponentialphase cultures $\left(\mathrm{OD}_{600} \sim 0 \cdot 5\right)$, grown as indicated, using the RNeasy kit (Qiagen). A sample $(50 \mathrm{ml})$ of culture was washed in $1 \mathrm{ml}$ medium and resuspended in $100 \mu \mathrm{l}$ TE $(10 \mathrm{mM}$ Tris/ $\mathrm{HCl}, 1 \mathrm{mM}$ EDTA, $\mathrm{pH} 8 \cdot 0$ ). After the addition of $5 \mu \mathrm{l} 10 \%$ Triton X-100, the RNA was further purified according to the manufacturer's instructions, except that genomic DNA was sheared through a $0.45 \mathrm{~mm}$ needle before the sample was applied to a spin column. Columns were eluted twice with $50 \mu \mathrm{l}$ water. For the determination of the transcription start sites of $\operatorname{cop} T$ and the copMA messenger, primer extension analysis was performed using the following radiolabelled antisense oligonucleotides: BG1131 (5'-GTGCTCCTACTGATATTAAGCC-3') for $\operatorname{cop} T$ and BG1130 (5'-CATGTTGCACAATGCATCCC-3') for copMA. These primers were end-labelled using $\mathrm{T} 4$ kinase (Invitrogen) and radioactive $\left[\gamma-{ }^{32} \mathrm{P}\right] \mathrm{ATP}$ (Amersham Biosciences), according to the manufacturer's instructions. For determination of $\operatorname{cop} T$ and $\operatorname{cop} M A$ expression levels upon addition of various metal salts (see Fig. $4 \mathrm{a}$ and b), the same oligonucleotides were used. As an internal control for RNA levels, an antisense oligonucleotide for the gad gene (BG2046, 5'-CAGATATAACTCTTAGTGTGGGTAC-3') was used. The gad gene encodes glycolytic gluconate dehydratase (Ahmed et al., 2005) and its expression is expected to be unaffected by the addition of metal salts.

For the primer extension reaction, $10 \mu \mathrm{g}$ total RNA and $2 \cdot 5 \mathrm{ng}$ radiolabelled oligonucleotide were resuspended in $2 \times$ AMV-RT buffer (Promega) in a final volume of $25 \mu \mathrm{l}$. Samples were heated to $70{ }^{\circ} \mathrm{C}$ for $10 \mathrm{~min}$ and slowly cooled to room temperature. $\mathrm{MgCl}_{2}, \mathrm{dNTPs}$, RNasin and AMV-RT (Promega) were added to concentrations of $5 \mathrm{mM}, 0 \cdot 4 \mathrm{mM}, 0 \cdot 8$ units $\mu \mathrm{l}^{-1}$ and 0.4 units $\mu \mathrm{l}^{-1}$, respectively, in a final volume of $50 \mu$ l. The samples were incubated at $42^{\circ} \mathrm{C}$ for $30 \mathrm{~min}$, extracted with phenol/chloroform, precipitated with ethanol and resuspended in formamide loading buffer. The primer extension products were analysed on an $8 \%$ denaturing sequencing gel along with a sequence ladder that was generated using the same radiolabelled oligonucleotides. After drying, the gels were exposed to a phosphor screen (Amersham Biosciences) and analysed using a molecular imager (Storm 860; Molecular Dynamics). Primer extension products were quantified using ImageQuant software (Molecular Dynamics).

Recombinant production and purification of CopT and LrpA. The $\operatorname{cop} T$ gene was PCR-amplified from S. solfataricus genomic DNA using the primers BG864 (5'-CGCGCCATGGAAAAGTTGACAGATTTAGAGTTTAG-3') and BG865 (5'- CGCGCGGATCCTAATGTAAGTGCAAGCCATTGTTG $-3^{\prime}$ ), which contain $\mathrm{NcoI}$ and 
BamHI restriction sites, respectively (underlined). The generated PCR fragment was cloned into NcoI/BamHI-digested pET24d expression vector (Novagen), resulting in pWUR59. The sequence of the cloned $\operatorname{cop} T$ gene was verified by dideoxy sequencing and was subsequently transformed into the Escherichia coli expression strain JM109(DE3)-pRIL (Novagen) to produce CopT protein. E. coli cells harbouring pWUR59 were grown at $37^{\circ} \mathrm{C}$ in $11 \mathrm{LB}$ medium to an $\mathrm{OD}_{600}$ of $0 \cdot 5$, and CopT expression was induced by the addition of IPTG to a final concentration of $0.4 \mathrm{mM}$. After overnight incubation at $37^{\circ} \mathrm{C}$, the cells were harvested by centrifugation for $10 \mathrm{~min}$ at $5000 \mathrm{~g}$. Routinely, a bacterial cell pellet derived from $500 \mathrm{ml}$ expression culture was resuspended in $20 \mathrm{ml}$ buffer P (20 mM Tris/ $\mathrm{HCl}, \mathrm{pH} 7 \cdot 0,10 \mathrm{mM}$ DTT) containing one complete mini protease inhibitor cocktail tablet (Roche) and subjected to cell lysis by sonification. After cell lysis, the cleared cell lysate was subjected to heat treatment $\left(30 \mathrm{~min}\right.$ at $\left.80^{\circ} \mathrm{C}\right)$ and subsequently centrifuged for $30 \mathrm{~min}$ at $16000 \mathrm{~g}$. Recombinant CopT was then purified to apparent homogeneity by size exclusion chromatography using a Superdex 200 10/300 GL column (Amersham Biosciences), which was preequilibrated with buffer $S(20 \mathrm{mM}$ Tris/ $\mathrm{HCl}, \mathrm{pH} 7 \cdot 0,0 \cdot 1 \mathrm{M} \mathrm{NaCl}$, $10 \mathrm{mM}$ DTT). Fractions containing pure CopT were pooled and flushed in an anaerobic chamber to remove residual oxygen molecules. Recombinant CopT was stored at $4{ }^{\circ} \mathrm{C}$. Typically, a $500 \mathrm{ml}$ expression culture harvested approximately $5 \mathrm{mg}$ electrophoretically pure CopT.

Recombinant LrpA from Pyrococcus furiosus was produced and purified as described previously (Brinkman et al., 2000).

\section{Electrophoretic mobility shift assays (EMSA) and DNase I footprinting. DNA probes for EMSA were generated using PCR with the primer pair BG1081 (5'-ACTAGTTGGATGGATATTAGG- AATAGC- $\left.3^{\prime}\right)$ and BG1082 (5'-TCTCTTAAAATCTCCAGCGCTC- $\left.3^{\prime}\right)$ for the $\operatorname{cop} T$ promoter fragment $\left(\mathrm{P}_{\operatorname{cop} T}\right.$, see also Fig. $\left.5 \mathrm{~b}\right)$ and primer

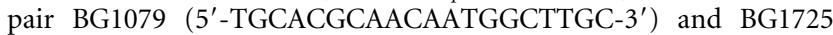 (5'-GACAATGAGATGAGCAGAAATAG-3') for the copMA promoter fragment $\left(\mathrm{P}_{\text {copMA }}\right.$, see also see Fig. 5b). Subfragments of the copMA promoter fragment were generated using primer pair BG1770 $\left(5^{\prime}\right.$. CAATGGCTTGCACTTACATTA-3') and BG1771 (5'-CTTCTGT- AAATTTGTATCTATATA-3' ${ }^{\prime}$ ) for $\mathrm{P}_{\text {copMA }}$-I, primer pair BG1772 (5'-GAAAAGGTTCTTTATAATAAAAG-3') and BG1773 (5'-CTA- ATTATTGCTTTTATTATAAAG-3') for $\mathrm{P}_{c o p M A}$-II, and primer pair BG1774 (5'-GATAATCGATCCGGTTTGTGG-3') and BG1775 (5'- GATTTTTCCCTTATACATTGTC-3') for $\mathrm{P}_{\text {copMA }}$-III (also see Fig. 7a). PCR products were end-labelled using T4 kinase (Invitrogen) and radioactive $\left[\gamma_{-}{ }^{32} \mathrm{P}\right]$ ATP (Amersham Biosciences), and purified from a $6 \%$ polyacrylamide gel. Binding reactions were performed in bind- ing buffer $\mathrm{B}(50 \mathrm{mM}$ Tris/ $\mathrm{HCl}, \mathrm{pH} 8 \cdot 0,1 \mathrm{mM} \mathrm{DTT}, 5 \%$ glycerol $(\mathrm{w} / \mathrm{v}), 5 \mathrm{ng}$ poly(dI.dC).poly(dI.dC) $\left.\mu^{-1}\right)$. CopT and metals, if pre- sent, were added to final concentrations as indicated and reactions were incubated at room temperature $\left(\mathrm{P}_{\text {copMA }}\right.$-I, $\mathrm{P}_{\text {cop } M A}$-II, $\mathrm{P}_{\text {copMA }}$-III $)$ or at $50{ }^{\circ} \mathrm{C}\left(\mathrm{P}_{c o p T}, \mathrm{P}_{c o p M A}\right)$ for $20 \mathrm{~min}$. The protein-DNA complexes thus obtained were separated on a non-denaturing $12 \%\left(\mathrm{P}_{\text {copMA }}-\mathrm{I}\right.$, $\left.\mathrm{P}_{\text {copMA-II, }} \mathrm{P}_{\text {copMA-III }}\right)$ or $6 \%\left(\mathrm{P}_{c o p T}, \mathrm{P}_{c o p M A}\right)$ polyacrylamide gel, buffered in $1 \times$ TBE buffer. Gels were then dried, exposed to a phos- phor screen (Amersham Biosciences) and analysed using a molecular imager (Storm 860; Molecular Dynamics). EMSA using P. furiosus LrpA was performed as described previously (Brinkman et al., 2000).}

For DNase I footprinting, a $\mathrm{P}_{\text {copMA }}$ probe was generated using PCR with the oligonucleotides BG1079 and BG1725, by end-labelling one of the two oligonucleotides using T4 kinase (Invitrogen) and radioactive $\left[\gamma-{ }^{32} \mathrm{P}\right]$ ATP (Amersham Biosciences). Probes were purified from a $6 \%$ polyacrylamide gel. The binding reactions contained $2.5 \mathrm{ng}$ labelled probe ( $\sim 50$ c.p.s.) and $1 \mu \mathrm{g}$ CopT, and were performed at $50{ }^{\circ} \mathrm{C}$ in a total volume of $50 \mu \mathrm{l}$ containing $50 \mathrm{mM}$ Tris/ $\mathrm{HCl}, \mathrm{pH} 8 \cdot 0,25 \mathrm{mM}$ $\mathrm{MgCl}_{2}, 75 \mathrm{mM} \mathrm{KCl}$ and $1 \mathrm{mM}$ DTT. After $20 \mathrm{~min}$, the reaction was cooled to $48^{\circ} \mathrm{C}$ and $1 \mu \mathrm{l}$ of a $1: 50$ dilution (approx. 0.6 units) of RNase-free DNase I (Roche) was added. Incubation was then allowed to continue for $1 \mathrm{~min}$. The reaction was terminated by the addition of buffer T $(250 \mu \mathrm{l} 10 \mathrm{mM}$ Tris/ $\mathrm{HCl}, \mathrm{pH} 8 \cdot 0,10 \mathrm{mM}$ EDTA, $750 \mathrm{mM}$ $\mathrm{NaCl}, 1 \% \mathrm{SDS}, 0 \cdot 04 \mu \mathrm{g}$ glycogen $\mu^{-1}$ ) and the samples were purified using phenol/chloroform extraction and ethanol precipitation. After resuspension in formamide loading buffer, the samples were analysed on a $6 \%$ denaturing polyacrylamide gel along with a sequence ladder that was generated using the same radiolabelled oligonucleotides.

\section{RESULTS}

\section{Analysis of the S. solfataricus cop gene cluster}

We have previously reported the discovery of a putative archaeal copper (cop) resistance gene cluster (Ettema et al., 2003). This cop cluster was found to be conserved in several euryarchaeal and crenarchaeal genomes, amongst which is the genome of the aerobic thermoacidophile $S$. solfataricus (Ettema et al., 2003) (Fig. 1). In this organism, the cop cluster consists of tandem-orientated genes encoding a putative metallochaperone $(\operatorname{cop} M)$, a P-type cationtransporting ATPase $(\operatorname{cop} A)$ and an archaea-specific transcription regulator (copT) (Fig. 1). The $\operatorname{cop} M$ and $\operatorname{cop} A$ genes in S. solfataricus overlap by $32 \mathrm{bp}$, which strongly suggests that these genes are transcribed as a single messenger. Domain architecture analysis reveals that CopT contains an N-terminal helix-turn-helix (HTH) motif (Fig. 2) that resembles the DNA-binding motifs of prokaryotic transcriptional regulators, such as MarR, IclR and Lrp (Brinkman et al., 2003). The presence of these typical prokaryotic HTH motifs has resulted in the mis-annotation of CopT proteins as being members of the Lrp family of transcriptional regulators. However, CopT proteins lack a C-terminal RAM domain (Ettema et al., 2002), which is the characteristic ligand-binding domain of Lrp-like proteins (Brinkman et al., 2003). Instead, the C-terminal part of CopT contains a putative metal-binding TRASH domain (Ettema et al., 2003), consisting of a conserved cysteine motif that is located within a 30 aa region (Fig. 2).

\section{Expression of cop genes in S. solfataricus}

The cop operon of $S$. solfataricus consists of the tandemly orientated $\operatorname{cop} T$ gene and the copMA gene pair (Fig. 1). To determine the role of the genes of this cluster, the expression of the cop genes was analysed under various conditions. First, the MIC of different metals was determined for $S$. solfataricus (Table 1). The obtained MIC values resembled the values reported by Grogan (1989), except for $\mathrm{Cd}^{2+}$ and $\mathrm{Zn}^{2+}$, which were found to be slightly higher (Table 1).

To determine the transcription start sites of the $\operatorname{cop} T$ and copMA transcripts, we separated the obtained primer extension products on a larger gel along with sequence reactions that were performed with the same $\operatorname{cop} T$ and copMA antisense primers. As shown in Fig. 3(a), copT transcription is initiated $1 \mathrm{bp}$ upstream of the predicted start codon of the $\operatorname{cop} T$ gene, whereas transcription of copMA is initiated 2 bp upstream of the predicted copM start 


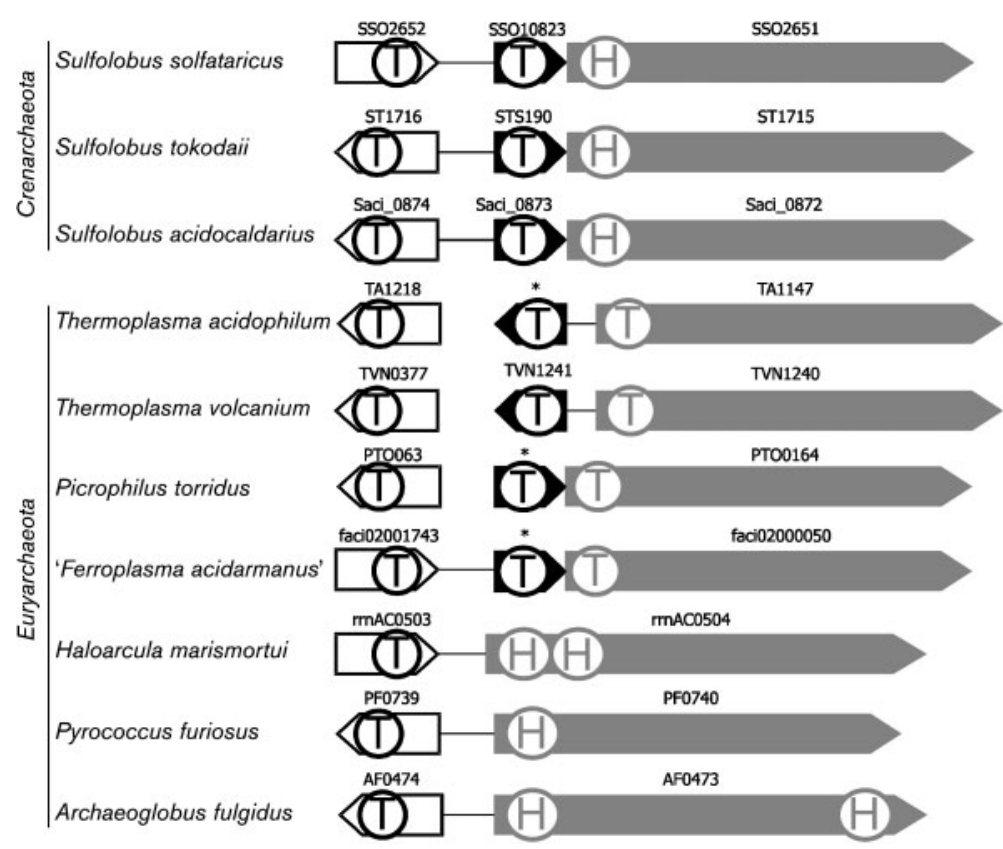

Fig. 1. Conserved gene organization of archaeal cop loci. Genes encoding CopT, CopM and CopA are indicated with white, black and grey arrows respectively. Drawn lines indicate a physical linkage between genes. Gene numbers are indicated above the genes. Genes that have been overlooked in genome annotation and are absent from protein databases are indicated with an asterisk. Genes are drawn approximately to scale. Domain abbreviations: T, TRASH domain; H, HMA domain. (Adapted from Ettema et al., 2003.)

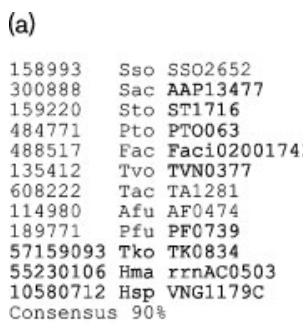

Consensus 90 ?

(b)

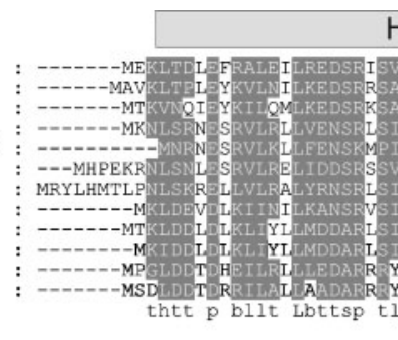

\section{HTH}
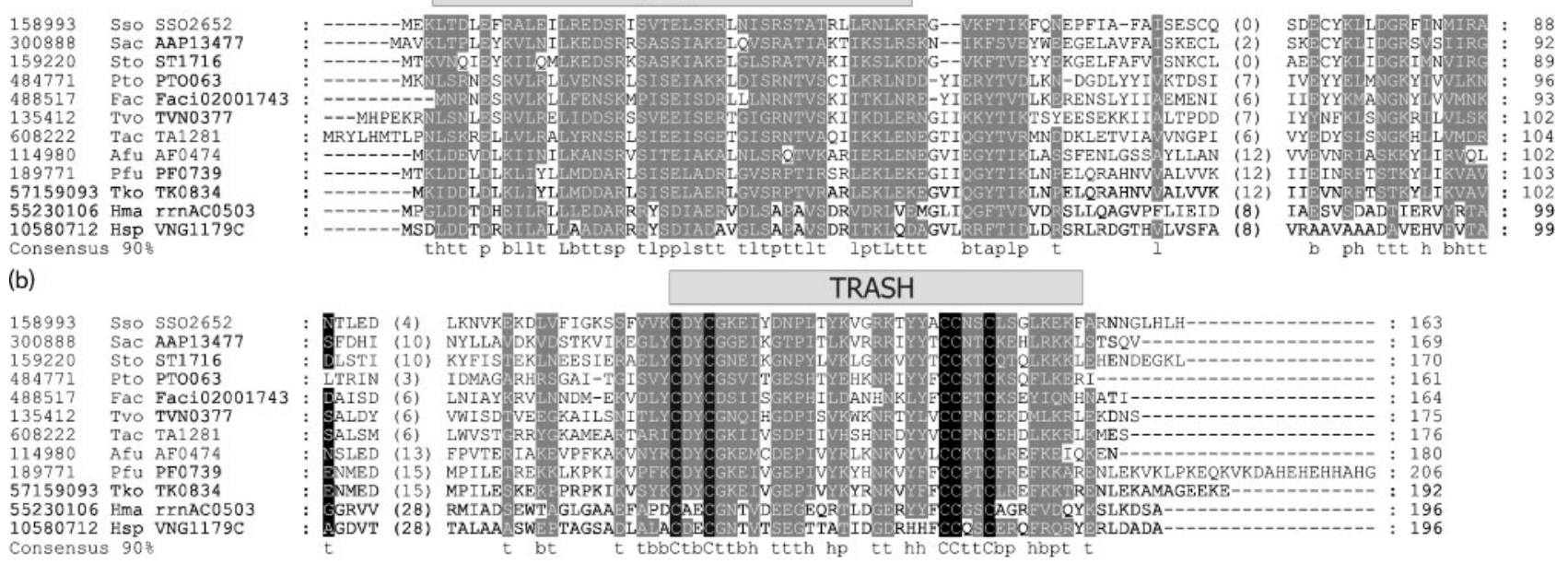

Fig. 2. Sequence analysis of CopT. (a) Multiple alignment of the core of archaeal CopT proteins. The sequences are denoted as in Fig. 1 (except that for S. acidocaldarius CopT a locus entry is provided). The positions of the first and the last residue of the aligned region in the corresponding protein are indicated for each sequence. The $90 \%$ consensus sequence shown below the alignments was obtained using the following amino acid classes: aromatic ( $a, \mathrm{FYW})$, small $(s, \mathrm{GASC})$, charged $(p$, STEDKRNQH), turn-forming ( $t$, ASTDNVGPENRK), big ( $b$, FILMVWYKREQ) and hydrophobic ( $h$, ACFILMVWYH), of which the aliphatic subset (I, ILVA) residues that show $100 \%$ conservation are indicated in capitals. Residues conserved $>90 \%$ are shown in white type on a grey background. Conserved cysteine residues that have been predicted to be involved in metal binding are shown in white type on a black background. The location of a putative HTH motif and the TRASH domain are indicated above the alignment. The numbers within the alignment represent poorly conserved inserts that are not shown. For the CopT sequences of $P$. furiosus (PF0739) and Halobacterium sp. (VNG1179C), the transcription starts have been adjusted. Species abbreviations: Afu, Archaeoglobus fulgidus; Fac, 'Ferroplasma acidarmanus'; Hma, Haloarcula marismortui; Hsp, Halobacterium sp. NRC1; Pto, Picrophilus torridus; Pfu, Pyrococcus furiosus; Sac, Sulfolobus acidocaldarius; Sso, Sulfolobus solfataricus; Sto, Sulfolobus tokodaii; Tko, Thermococcus kodakaraensis; Tac, Thermoplasma acidophilum; Tvo, Thermoplasma volcanium. 
Table 1. MICs of various metal salts for $S$. solfataricus

\begin{tabular}{|lrr|}
\hline \multirow{2}{*}{ Salt } & \multicolumn{2}{c|}{ MIC $(\mu \mathrm{M})$} \\
\cline { 2 - 3 } & Grogan (1989) & This study \\
\hline EDTA & - & $<1000$ \\
$\mathrm{CuSO}_{4}$ & 5000 & 5000 \\
$\mathrm{Ag}_{2} \mathrm{SO}_{4}$ & 8 & 8 \\
$\mathrm{CdCl}_{2}$ & 2000 & $>4000$ \\
$\mathrm{ZnSO}_{4}$ & 50000 & $>75000$ \\
$\mathrm{NiSO}_{4}$ & 600 & 600 \\
\hline
\end{tabular}

codon (Fig. 3b). We could not detect bands corresponding to a smaller primer extension product (not shown), suggesting that the $\operatorname{cop} M$ and $\operatorname{cop} A$ genes are transcribed as a polycistronic mRNA, initiated from a single promoter upstream of $с о р M$. Sequence elements matching $S$. solfataricus consensus TATA boxes and BREs (Bell et al., 1999b) are present upstream of the two mapped transcriptional starts (Fig. 3a, b). The copMA genes of 'Ferroplasma acidarmanus' (referred to as $\operatorname{cop} Z B$ ) have also been shown to be expressed as a polycistronic messenger (Baker-Austin et al., 2005).

To analyse the transcription regulation of the cop operon, different metals were added to an S. solfataricus culture that was growing exponentially in defined medium, at a concentration that was equivalent to the determined MIC value. Subsequently, total RNA was isolated and analysed using primer extension analysis using antisense primers for copT and copMA. As shown in Fig. 4(a), transcription of copT is constitutive under the tested conditions, whereas transcription of the copMA messenger is induced specifically in the presence of $\mathrm{Cu}^{2+}$ and $\mathrm{Cd}^{2+}$. Under non-induced conditions, copMA appears to be transcribed at a basal level, which decreases when the metal-chelating agent EDTA was added. In contrast, addition of EDTA had no apparent effect on $\operatorname{cop} T$ expression. It should be noted that addition of $1 \mathrm{mM}$ EDTA immediately abolished growth of $S$. solfataricus. Induction of copMA transcription by $\mathrm{Cu}^{2+}$ was further studied by isolation of total RNA from an S. solfataricus culture at different time intervals. Transcription of copMA was significantly induced after $30 \mathrm{~min}$, and the transcript concentration gradually increased during the first $3 \mathrm{~h}$ after induction to a level more than 14-fold higher than the basal transcription level (Fig. 4b). To determine whether basal copMA transcription is due to the small amount of $\mathrm{Cu}^{2+}$ $(0 \cdot 45 \mu \mathrm{M})$ present in the defined medium, copMA transcription was also determined in defined medium from which $\mathrm{Cu}^{2+}$ was omitted. Although no significant decrease in basal transcription was observed (results not shown), we (a)

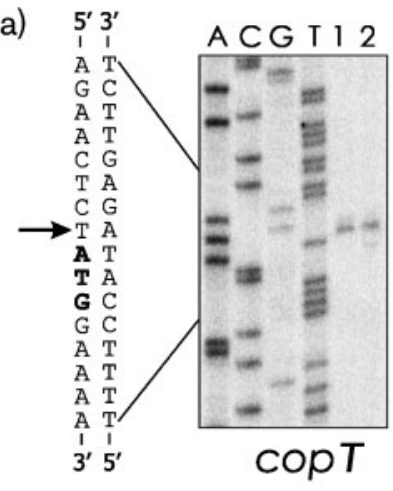

(b)

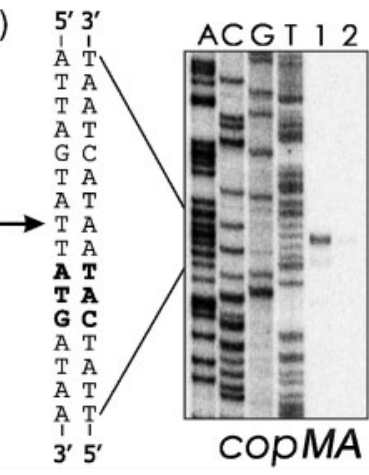

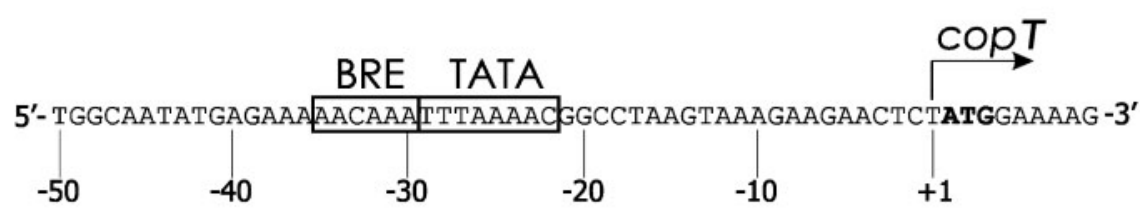

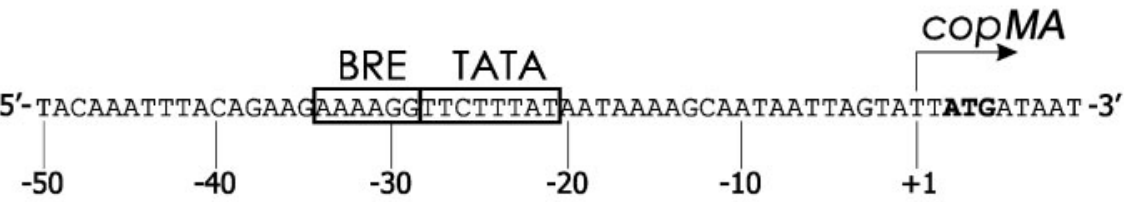

$-50$

$-30$

$-20$

$-10$

$+1$

Fig. 3. Mapping of the transcription start sites of copT and copMA genes. Primer extension products of $\operatorname{cop} T$ (a) and copMA (b) were analysed on a sequencing gel along with a sequence ladder. Lanes 1 and 2 contain primer extension products using RNA from $\mathrm{CuSO}_{4}$-induced cells and non-induced cells, respectively. The transcriptional start sites of copT and copMA are indicated with an arrow $(+1)$, and presumptive BREs and TATA boxes are indicated by rectangles. 
(a)
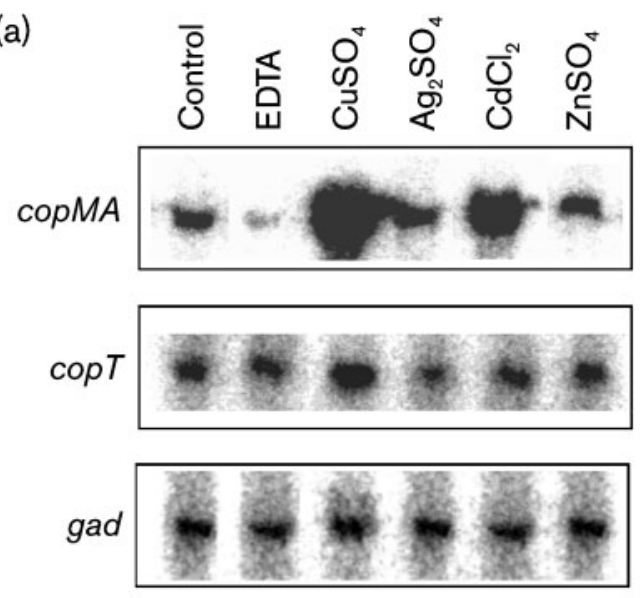

(b)
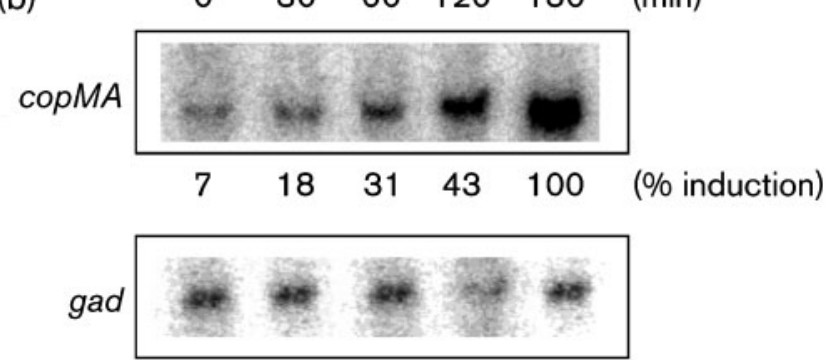

Fig. 4. copMA transcript levels accumulate upon exposure to elevated $\mathrm{CuSO}_{4}$ and $\mathrm{CdCl}_{2}$ levels. Effect of addition of different metals on expression levels of copT and copMA (a). MICs of EDTA and various metals (see Table 1) were added to an exponentially growing $S$. solfataricus culture. EDTA, $1 \mathrm{mM}$; $\mathrm{CuSO}_{4}, 5 \mathrm{mM} ; \mathrm{Ag}_{2} \mathrm{SO}_{4}, 8 \mu \mathrm{M} ; \mathrm{CdCl}_{2}, 4 \mathrm{mM} ; \mathrm{ZnSO}_{4}, 75 \mathrm{mM}$. Four hours after addition of EDTA or metals, total RNA was isolated and analysed using primer extension with $\operatorname{cop} T$ and copMA antisense primers. (b) Induction of $\operatorname{cop} M A$ transcription by $\mathrm{CuSO}_{4}$ was further studied at different time intervals $(0,30$, 60,120 and $180 \mathrm{~min}$ after addition of $5 \mathrm{mM} \mathrm{CuSO}$ ). As an internal control, the gad (encoding $S$. solfataricus gluconate dehydratase) primer extension product is shown.

cannot rule out the possibility that trace amounts of $\mathrm{Cu}^{2+}$ were still present in the demineralized water that was used to prepare the defined medium. These results are in good agreement with the recently published study of copper resistance of another archaeon, ' $F$. acidarmanus' (BakerAustin et al., 2005). In this study, a 15 -fold induction of the bicistronic copMA transcript (referred to as $c o p Z B$ ) was reported upon exposure to elevated levels of copper ( $5 \mathrm{~g}$ $\mathrm{CuSO}_{4} \mathrm{l}^{-1}$ ), whereas the expression of the $\operatorname{cop} T$ gene (referred to as $c o p Y$ ) was unaffected upon addition of copper (Baker-Austin et al., 2005). In contrast, expression of the ' $F$. acidarmanus' copMA genes was not induced upon addition of cadmium, like the copMA genes of $S$. solfataricus.

We conclude that the genes in the cop regulon in S. solfataricus are most probably involved in the efflux of copper and cadmium, since these metals specifically induce expression of the copMA transcript. As with many transcriptional regulators, $\operatorname{cop} T$ expression appears to be maintained at a constitutive level under the tested conditions.

\section{CopT specifically targets the copMA promoter}

The copT gene was cloned into the pET24d expression vector (Novagen) and functionally overproduced in E. coli. Subsequently, CopT was purified to electrophoretic homogeneity as described in Methods (Fig. 5a). To prevent undesired protein aggregation, the purified CopT protein was stored under anoxic conditions in the presence of excess amounts of DTT $(10 \mathrm{mM})$. Subsequently, purified CopT was used in EMSAs to determine whether it binds to the mapped copT and copMA promoters $\left(\mathrm{P}_{c o p T}, \mathrm{P}_{c o p M A}\right.$; Fig. 5b). CopT was unable to bind to the $200 \mathrm{bp} \mathrm{P}_{c o p T}$ fragment under the tested conditions (Fig. 5c). This finding is in agreement with the observation that $\operatorname{cop} T$ expression is constitutive under all tested conditions and suggests that CopT does not autoregulate its own expression. In contrast, transcriptional regulators of well characterized cop regulons of E. coli (CueR) (Outten et al., 2000; Stoyanov et al., 2001) and Enterococcus hirae (CopY) (Strausak \& Solioz, 1997) are subjected to autoregulation.

Binding of CopT to a $222 \mathrm{bp}$ DNA fragment containing the copMA promoter was observed (Fig. 5e). EMSA experiments revealed that after the first CopT-DNA complex (complex 1) was formed, four additional complexes of distinct electrophoretic mobility were formed with increasing CopT concentration (Fig. 5d). This suggests that multiple CopT-binding sites are present in $\mathrm{P}_{\text {copMA }}$.

\section{$\mathrm{Cu}^{2+}$ modulates the CopT-DNA interaction}

Because transcription analysis showed that both $\mathrm{Cu}^{2+}$ and $\mathrm{Cd}^{2+}$ induce expression of the copMA operon, we investigated the effect of adding metal ions on the formation of CopT-DNA complexes. Addition of $\mathrm{Cu}^{2+}$ to the binding reaction was found to reduce the DNA-binding capacity of CopT (Fig. 5d), whereas addition of copper did not affect the binding of an unrelated archaeal transcriptional regulator (LrpA; Brinkman et al., 2000) to its target promoter $\left(\mathrm{P}_{l r p A}\right)$ (Fig. 5e); this strongly suggests a specific effect of copper on CopT functionality. Although $\mathrm{Cd}^{2+}$ induced copMA expression (addition of $\mathrm{Cd}^{2+}$ only has marginal effects on CopT-DNA complex formation), as reflected by a slight decrease of complex 1, the intensity of complex 5 slightly increased (Fig. 5d).

To study the effect of $\mathrm{Cu}^{2+}$ on CopT-DNA complex formation in more detail, EMSA analysis was performed with $\mathrm{P}_{\text {copMA }}$ and increasing amounts of CopT in either the presence or absence of $\mathrm{Cu}^{2+}$ (Fig. 5f). The addition of $\mathrm{Cu}^{2+}$ to the binding reaction affected CopT-DNA binding in two ways. First, the overall binding affinity decreased, and second, the formation of complex 1 (Fig. $5 \mathrm{f}$ ) was completely obliterated. It is proposed that exogenous $\mathrm{Cu}^{2+}$ binds 
(a)

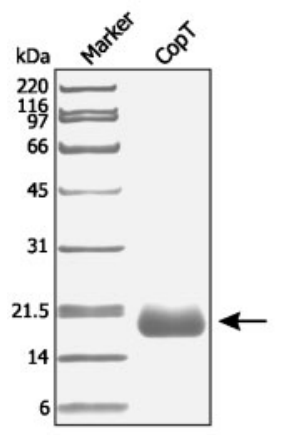

(d)

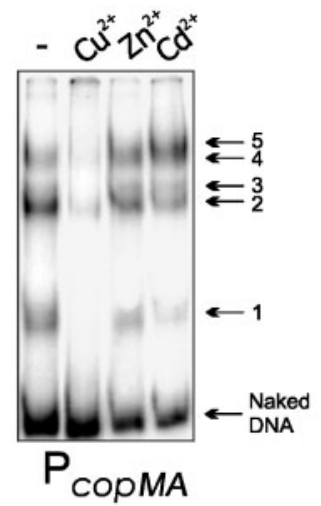

(b)

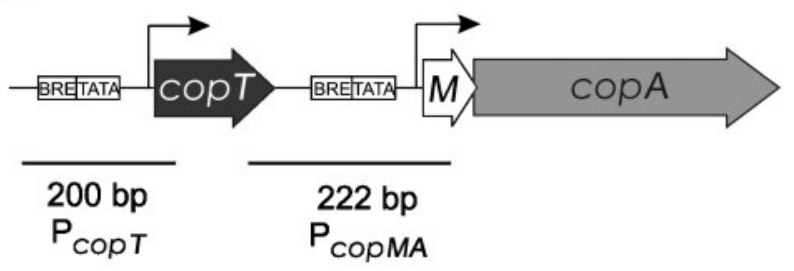

(c)

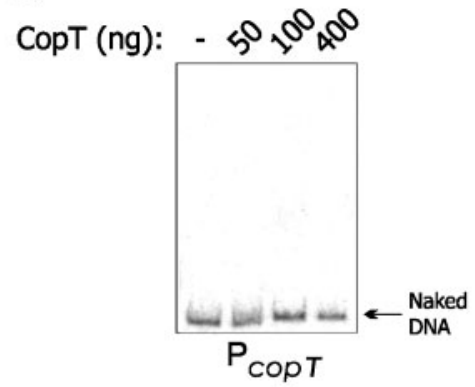

(e)

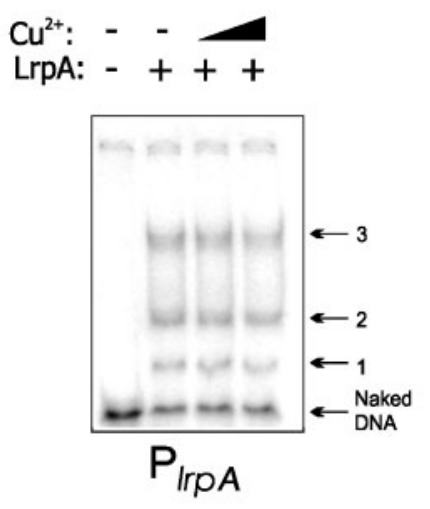

(f)

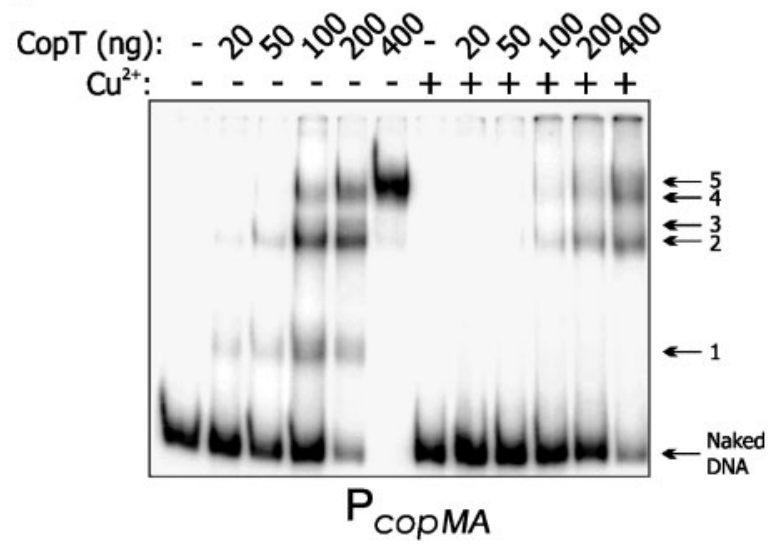

Fig. 5. CopT binds to the copMA promoter, but not to its own promoter. (a) SDS-PAGE analysis of purified CopT. The arrow indicates a single band that corresponds to the size of a CopT monomer. (b) Schematic display of the DNA fragments used

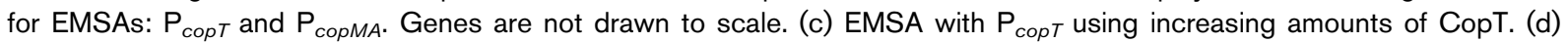
EMSA with $\mathrm{P}_{\text {copMA }}$ using increasing amounts of CopT. The five different CopT-DNA complexes are numbered 1-5, respectively. (d) Effects of various metal ions on CopT-DNA binding. Binding reactions were performed as described in Methods and contained $200 \mathrm{ng}$ CopT. Metal salts were added to a final concentration of $100 \mu \mathrm{M}$. (e) Control experiment showing that addition of different concentrations of copper ions $\left(0,10\right.$ and $\left.100 \mu \mathrm{M} \mathrm{CuSO}_{4}\right)$ to an unrelated archaeal transcriptional regulator ( $\mathrm{LrpA}$ ) has no effect on binding to its target promoter, $\mathrm{P}_{\text {IrpA. }}$. (f) Effect of $\mathrm{Cu}^{2+}$ on CopT-DNA binding at different concentrations of CopT. Assays were performed in the presence or absence of $100 \mu \mathrm{M} \mathrm{CuSO}_{4}$.

to the TRASH domain, to cause an allosteric conformational change in CopT, resulting in an altered DNA-binding mode involving a lower DNA-binding affinity and perhaps different multimerization properties. Consequently, this enables the initiation of transcription of the copMA genes. Together with the observed induction of copMA transcription upon exposure to excess levels of exogenous copper in vivo, it is suggested that CopT is a repressor of copMA transcription and that transcription occurs by copperCopT-mediated derepression.

\section{CopT binds to multiple binding sites at the copMA promoter}

To determine the locations where CopT interacts with the copMA promoter, DNase I footprinting was performed (Fig. 6a). CopT protects $\mathrm{P}_{\text {copMA }}$ at multiple locations, suggesting the presence of multiple CopT-binding sites (Fig. 6b, c). However, close examination of the protected regions did not reveal the presence of any type of CopT consensus motif. In addition, extensive searches for putative $\operatorname{cop}$ motifs (including palindromic sequences, direct and indirect repeats and other conserved motifs) in the cop gene clusters of other archaeal species (as displayed in Fig. 1) did not result in the identification of any conserved motif (T. J. G. Ettema \& J. Van der Oost, unpublished results). The absence of such a motif implies either the existence of a very degenerative cop motif or that specific DNA recognition by CopT is accomplished by other, hitherto unknown determinants.

The regions that were protected by CopT in the DNase I footprint assay are located both upstream and downstream of the putative TATA box and BRE sequence, but do not 


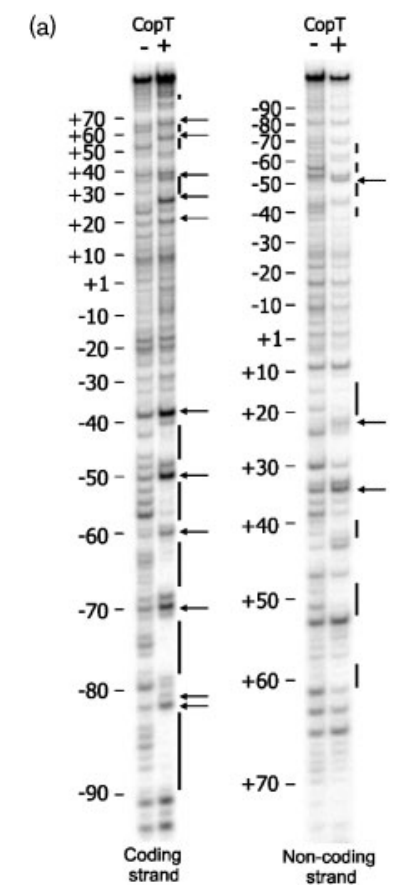

(b)

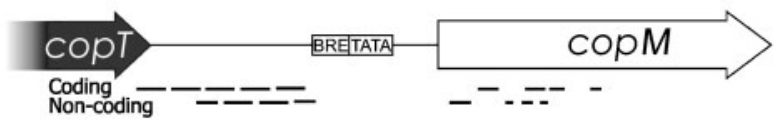

(c)
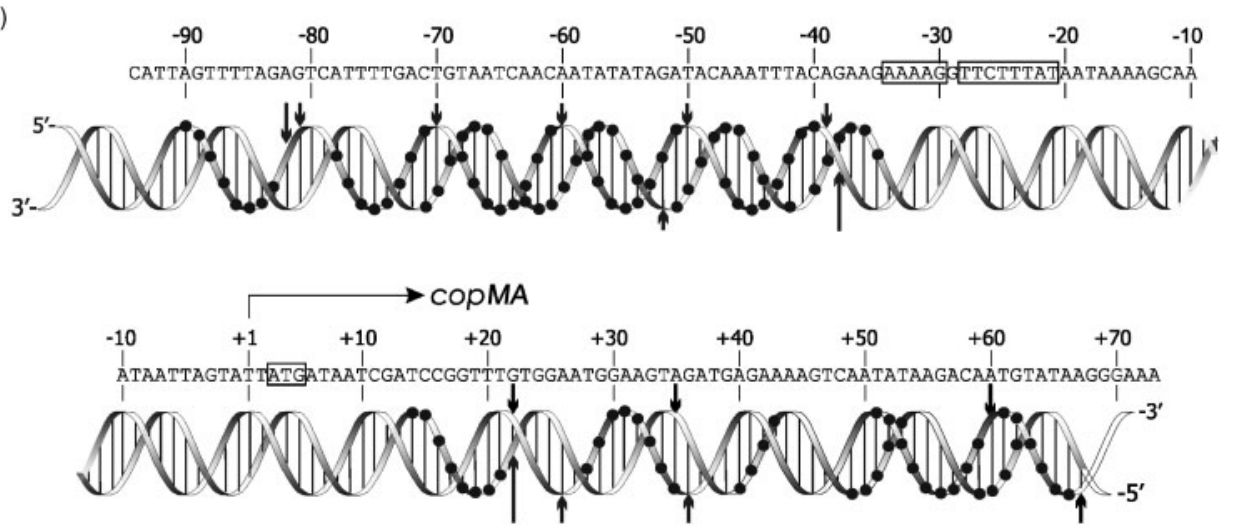

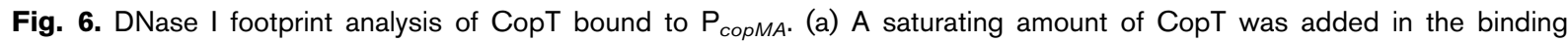
reaction as described in Methods and compared to a reaction lacking CopT. Sequence ladders are shown for the coding and non-coding strand and protected bases are indicated by vertical bars. DNase I hypersensitive sites are indicated by a

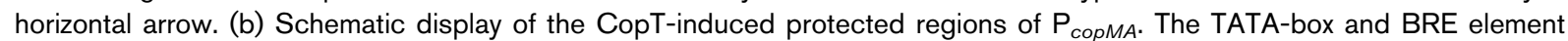
are shown. (c) Imposition of the DNase I footprinting results on a double-helical representation of the copMA promoter region. Filled circles indicate sites that were protected during DNase I degradation and bold arrows indicate DNase I hypersensitive sites. The sequence of the non-template strand is indicated above the helical representation, and boxed sequences indicate the TATA-box, BRE element and start codon (ATG). The sequence positions are relative to the copMA transcription start site $(+1)$, which is indicated by an arrow.

overlap with these elements. This suggests that, potentially, the recruitment of basal transcription factors TFB (transcription factor B) and TBP (TATA-box-binding protein) is not prevented by the presence of CopT on $\mathrm{P}_{\text {copMA }}$.

To study differential binding affinity of CopT for binding sites up and downstream of the TATA-BRE region, EMSAs were performed with different subfragments of $\mathrm{P}_{\text {copMA }}$ (Fig. 7a). Indeed, CopT bound only to the fragments upstream and downstream of this TATA-BRE region, but not to a $33 \mathrm{bp} \mathrm{P}_{\text {copMA }}$ fragment that includes the proposed TATA-BRE site (Fig. 7b, fragment II). This is in agreement with the results from the DNase I footprint assay. Addition of saturating amounts of CopT resulted in two complexes for each promoter fragment (Fig. 7b, fragments I and III). Addition of exogenous copper to the binding reaction appears to have a more severe effect on CopT binding to fragment III than to fragment I. For fragment III (Fig. 7b, right panel), the amount of CopT-bound probe dropped from $88 \%$ (no copper added) to $16 \%\left(500 \mu \mathrm{M} \mathrm{CuSO}_{4}\right.$ added), whereas only a marginal effect was observed for fragment I, where the amount of CopT-bound probe only dropped from 59 to $45 \%$ upon addition of $500 \mu \mathrm{M} \mathrm{CuSO}_{4}$ (Fig. 7b, left panel). It is concluded that CopT displays differential binding affinity to the sites on fragments I and III.

\section{DISCUSSION}

\section{A copper resistance gene cluster in S. solfataricus}

The present study describes the molecular characterization of a copper resistance gene cluster and its transcriptional regulator in the crenarchaeon $S$. solfataricus. This cop gene cluster is conserved in several archaeal genomes and encodes a putative metallochaperone ( $\operatorname{cop} M)$, a P-type cationtransporting ATPase $(\operatorname{cop} A)$ and an archaea-specific transcriptional regulator ( $\operatorname{cop} T$ ) (Fig. 1). When S. solfataricus is challenged by the addition of various metals, we have shown that the polycistronic copMA transcript is found to accumulate in response to growth-inhibiting copper and, to some extent, cadmium concentrations, whereas copT transcript abundance appeared to be constitutive. Increased levels of copMA expression will result in increased levels of CopA and CopM protein. Whereas CopA is most probably involved in copper efflux, as has been shown for its 
(a)

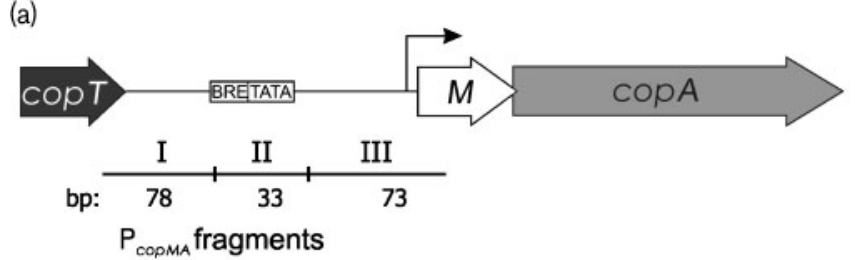

(b)

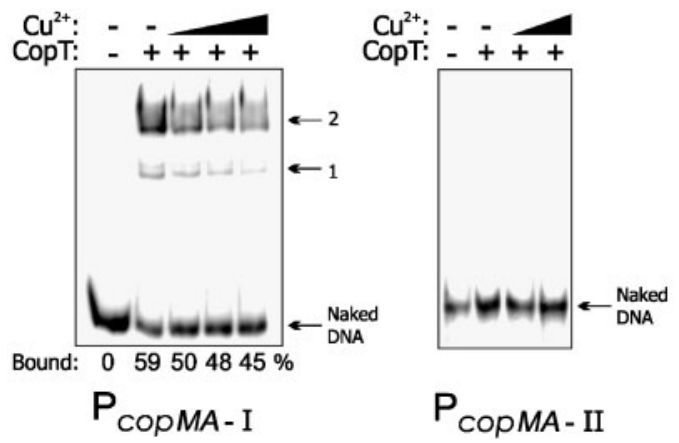

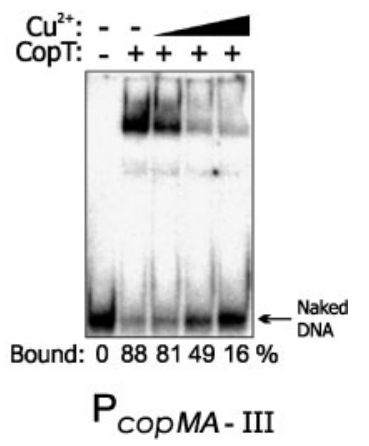

Fig. 7. Binding of CopT to copMA promoter fragments up- and downstream of the predicted TATA-box and BRE element is differentially influenced by exogenous $\mathrm{Cu}^{2+}$. (a) Schematic display of the different DNA fragments used for EMSA analysis $\left(P_{\text {copMA-I, }}-\right.$ II and -III). (b) EMSA with CopT, $\mathrm{P}_{\text {copMA }}$ fragments and $\mathrm{CuSO}_{4}$. Where indicated $(+)$, $400 \mathrm{ng}$ CopT was added to the binding reactions. The different CopT-DNA complexes are indicated. $\mathrm{CuSO}_{4}$ was added to final concentrations of 10,100 or $500 \mu \mathrm{M}$. For fragment $\mathrm{P}_{\text {CopMA- }}$ II, the assay containing $100 \mu \mathrm{M} \mathrm{CuSO}_{4}$ was not performed. orthologue CopB in Archaeoglobus fulgidus (AF0474) (Mana-Capelli et al., 2003), the role of CopM remains to be established. Similarly to heavy-metal-associated domain (HMA)-type metallochaperones, CopM might play a role (i) in metallotrafficking-like functions (Hung et al., 1998; Multhaup et al., 2001; Tottey et al., 2002), (ii) in regulation of CopA activity (Hamza et al., 1999; Walker et al., 2002), or (iii) in modulation of transcriptional regulation (Cobine et al., 1999, 2002a, b).

The findings described above closely resemble the results recently published by Bond and co-workers, describing a molecular/proteomic study of proteins involved in copper resistance in the extreme acidophilic archaeon ' $F$. acidarmanus' Fer1 (Baker-Austin et al., 2005). They reported that the copM and сорA genes (which are referred to in their manuscript as $\operatorname{cop} Z$ and $\operatorname{cop} B$, respectively) in this organism are transcribed as a polycistronic messenger and are induced in response to high copper levels. Interestingly, the proteomic analysis of copper-induced ' $F$. acidarmanus' Fer1 cells revealed an accumulation of proteins involved in protein folding (thermosome subunits, molecular chaperones) and DNA repair. Most probably, this reflects a response to copper-mediated protein misfolding, and/or to free-radical formation (Baker-Austin et al., 2005).

\section{CopT, a copper-responsive transcription regulator of the cop gene cluster}

The putative transcriptional regulator CopT of $S$. solfataricus was successfully overexpressed in E. coli and purified to homogeneity. Subsequent DNA-binding studies revealed that CopT bound to multiple sites on the copMA promoter in vitro, and this interaction is specifically modulated upon the addition of copper. Coordinated binding of $\mathrm{Cu}^{2+}$ ions by the C-terminal TRASH domain of CopT is expected to result in an allosteric change in structural conformation, most likely resulting in a reduced DNA-binding affinity, and perhaps in a different multimeric state. Unfortunately, the creation of site-directed CopT mutant proteins containing single Cys-Ser mutations for each of the invariant cysteine residues was hampered due to the formation of insoluble protein aggregates (T. J. G. Ettema \& J. Van der Oost, unpublished results). This reduced the possibility of specifically studying the copper-dependence of DNA-binding by CopT and indicates that, besides playing an important role in selective binding of metal ions, these residues are strongly involved in maintaining the stability of the protein.

The results shown in this study are indicative of a copperresponsive transcriptional mechanism in which expression of the copMA messenger is stimulated via transcriptional derepression. This mechanism, which has been demonstrated for several archaeal transcription regulators, is characterized either by prevention of recruitment of the basal transcription factors TBP and TFB, or RNA polymerase, or by acting as a transcriptional roadblock, preventing transcription elongation by the RNA polymerase (Bell, 2005, and references therein).

MDR1 from A. fulgidus is the archaeal regulator for which the molecular mechanism of transcription regulation is understood in most detail (Bell et al., 1999a). This transcriptional repressor has been shown to recognize three operator sites on a promoter of a metal $\mathrm{ABC}$ transporter gene cluster in the presence of various metals in vitro and in vivo. Transcriptional repression was found to occur via impaired recruitment of RNA polymerase, while TFB and TBP were allowed to bind to their target sequences, governing a rapid transcriptional response after metal exposure (Bell et al., 1999b). Interestingly, CopT binds to sites both up- and downstream of the predicted TATA-BRE box 
(Fig. 6a-c), which is a peculiarity compared to archaeal transcriptional regulators acting as derepressors.

Based on the differential copper-induced binding affinity towards the binding sites upstream (fragment I) and downstream (fragment III) (Fig. 7), it is tempting to speculate that the latter binding sites are mainly involved in transcriptional repression, which is released upon the response to copper. Because CopT binding to the region upstream of the TATA-BRE fragment (fragment I) is less affected by exposure to copper, binding of CopT in this region may be constitutive in vivo, where it could enforce a stimulatory affect on transcription, possibly by interacting with basal transcription factors like TFB and TBP. However, the exact mechanism of CopT-mediated transcriptional regulation of copMA remains to be elucidated by future experiments.

Finally, it will be a major challenge to study the roles of the individual proteins encoded by the archaeal cop clusters, as well as their interactions, to elucidate the mechanism that governs TRASH-domain-mediated copper resistance in the archaea.

\section{ACKNOWLEDGEMENTS}

We thank N. J. Robinson (Medical School, Newcastle University) for helpful suggestions and for critically reading the manuscript prior to submission and S. D. Bell (Medical Research Council Cancer Cell Unit, Hutchison MRC Research Centre, Cambridge) for experimental advice.

\section{REFERENCES}

Ahmed, H., Ettema, T. J., Tjaden, B., Geerling, A. C., van der Oost, J. \& Siebers, B. (2005). The semi-phosphorylative Entner-Doudoroff pathway in hyperthermophilic archaea: a re-evaluation. Biochem $J$ 390, 539-540.

Aravind, L. \& Koonin, E. V. (1999). DNA-binding proteins and evolution of transcription regulation in the archaea. Nucleic Acids Res 27, 4658-4670.

Baker-Austin, C., Dopson, M., Wexler, M., Sawers, R. G. \& Bond, P. L. (2005). Molecular insight into extreme copper resistance in the extremophilic archaeon 'Ferroplasma acidarmanus' Fer1. Microbiology 151, 2637-2646.

Bell, S. D. (2005). Archaeal transcriptional regulation - variation on a bacterial theme? Trends Microbiol 13, 262-265.

Bell, S. D., Cairns, S. S., Robson, R. L. \& Jackson, S. P. (1999a), Transcriptional regulation of an archaeal operon in vivo and in vitro. Mol Cell 4, 971-982.

Bell, S. D., Kosa, P. L., Sigler, P. B. \& Jackson, S. P. (1999b). Orientation of the transcription preinitiation complex in archaea. Proc Natl Acad Sci U S A 96, 13662-13667.

Blindauer, C. A., Harrison, M. D., Robinson, A. K., Parkinson, J. A., Bowness, P. W., Sadler, P. J. \& Robinson, N. J. (2002). Multiple bacteria encode metallothioneins and SmtA-like zinc fingers. Mol Microbiol 45, 1421-1432.

Brinkman, A. B., Dahlke, I., Tuininga, J. E. \& 7 other authors (2000). An Lrp-like transcriptional regulator from the archaeon Pyrococcus furiosus is negatively autoregulated. J Biol Chem 275, 38160-38169.
Brinkman, A. B., Bell, S. D., Lebbink, R. J., de Vos, W. M. \& van der Oost, J. (2002). The Sulfolobus solfataricus Lrp-like protein LysM regulates lysine biosynthesis in response to lysine availability. J Biol Chem 277, 29537-29549.

Brinkman, A. B., Ettema, T. J., de Vos, W. M. \& van der Oost, J. (2003). The Lrp family of transcriptional regulators. Mol Microbiol 48, 287-294.

Brown, N. L., Stoyanov, J. V., Kidd, S. P. \& Hobman, J. L. (2003). The MerR family of transcriptional regulators. FEMS Microbiol Rev 27, 145-163.

Busenlehner, L. S., Pennella, M. A. \& Giedroc, D. P. (2003). The $\mathrm{SmtB} / \mathrm{ArsR}$ family of metalloregulatory transcriptional repressors: structural insights into prokaryotic metal resistance. FEMS Microbiol Rev 27, 131-143.

Camakaris, J., Voskoboinik, I. \& Mercer, J. F. (1999). Molecular mechanisms of copper homeostasis. Biochem Biophys Res Commun 261, 225-232.

Cavet, J. S., Borrelly, G. P. \& Robinson, N. J. (2003). Zn, Cu and Co in cyanobacteria: selective control of metal availability. FEMS Microbiol Rev 27, 165-181.

Cobine, P., Wickramasinghe, W. A., Harrison, M. D., Weber, T., Solioz, M. \& Dameron, C. T. (1999). The Enterococcus hirae copper chaperone CopZ delivers copper(I) to the CopY repressor. FEBS Lett 445, 27-30.

Cobine, P. A., George, G. N., Jones, C. E., Wickramasinghe, W. A., Solioz, M. \& Dameron, C. T. (2002a). Copper transfer from the $\mathrm{Cu}(\mathrm{I})$ chaperone, CopZ, to the repressor, $\mathrm{Zn}(\mathrm{II}) \mathrm{CopY}$ : metal coordination environments and protein interactions. Biochemistry 41, 5822-5829.

Cobine, P. A., Jones, C. E. \& Dameron, C. T. (2002b). Role for zinc(II) in the copper(I) regulated protein CopY. J Inorg Biochem 88, 192-196.

Degtyarenko, K. (2000). Bioinorganic motifs: towards functional classification of metalloproteins. Bioinformatics 16, 851-864.

Dixit, V., Bini, E., Drozda, M. \& Blum, P. (2004). Mercury inactivates transcription and the generalized transcription factor TFB in the archaeon Sulfolobus solfataricus. Antimicrob Agents Chemother 48, 1993-1999.

Edwards, K. J., Bond, P. L., Gihring, T. M. \& Banfield, J. F. (2000). An archaeal iron-oxidizing extreme acidophile important in acid mine drainage. Science 287, 1796-1799.

Ettema, T. J., Brinkman, A. B., Tani, T. H., Rafferty, J. B. \& Van Der Oost, J. (2002). A novel ligand-binding domain involved in regulation of amino acid metabolism in prokaryotes. J Biol Chem 277, 37464-37468.

Ettema, T. J., Huynen, M. A., de Vos, W. M. \& van der Oost, J. (2003) TRASH: a novel metal-binding domain predicted to be involved in heavy-metal sensing, trafficking and resistance. Trends Biochem Sci 28, 170-173.

Gregor, D. \& Pfeifer, F. (2001). Use of a halobacterial bgaH reporter gene to analyse the regulation of gene expression in halophilic archaea. Microbiology 147, 1745-1754.

Grogan, D. W. (1989). Phenotypic characterization of the archaebacterial genus Sulfolobus: comparison of five wild-type strains. J Bacteriol 171, 6710-6719.

Guedon, E. \& Helmann, J. D. (2003). Origins of metal ion selectivity in the DtxR/MntR family of metalloregulators. Mol Microbiol 48, 495-506.

Hamza, I., Schaefer, M., Klomp, L. W. \& Gitlin, J. D. (1999). Interaction of the copper chaperone HAH1 with the Wilson disease protein is essential for copper homeostasis. Proc Natl Acad Sci U S A 96, 13363-13368. 
Harrison, M. D., Jones, C. E., Solioz, M. \& Dameron, C. T. (2000). Intracellular copper routing: the role of copper chaperones. Trends Biochem Sci 25, 29-32.

Hochheimer, A., Hedderich, R. \& Thauer, R. K. (1999). The DNA binding protein Tfx from Methanobacterium thermoautotrophicum: structure, DNA binding properties and transcriptional regulation. Mol Microbiol 31, 641-650.

Hung, I. H., Casareno, R. L., Labesse, G., Mathews, F. S. \& Gitlin, J. D. (1998). HAH1 is a copper-binding protein with distinct amino acid residues mediating copper homeostasis and antioxidant defense. J Biol Chem 273, 1749-1754.

Letunic, I., Copley, R. R., Schmidt, S., Ciccarelli, F. D., Doerks, T., Schultz, J., Ponting, C. P. \& Bork, P. (2004). SMART 4.0: towards genomic data integration. Nucleic Acids Res 32, D142-D144.

Lutsenko, S. \& Kaplan, J. H. (1996). P-type ATPases. Trends Biochem Sci 21, 467.

Mana-Capelli, S., Mandal, A. K. \& Arguello, J. M. (2003). Archaeoglobus fulgidus $\mathrm{CopB}$ is a thermophilic $\mathrm{Cu}^{2+}$-ATPase: functional role of its histidine-rich-N-terminal metal binding domain. J Biol Chem 278, 40534-40541.

Mercer, J. F. (2001). The molecular basis of copper-transport diseases. Trends Mol Med 7, 64-69.

Multhaup, G., Strausak, D., Bissig, K. D. \& Solioz, M. (2001). Interaction of the CopZ copper chaperone with the CopA copper ATPase of Enterococcus hirae assessed by surface plasmon resonance. Biochem Biophys Res Commun 288, 172-177.

Nies, D. H. (1999). Microbial heavy-metal resistance. Appl Microbiol Biotechnol 51, 730-750.

Ouhammouch, M., Dewhurst, R. E., Hausner, W., Thomm, M. \& Geiduschek, E. P. (2003). Activation of archaeal transcription by recruitment of the TATA-binding protein. Proc Natl Acad Sci U S A 100, 5097-5102.

Outten, F. W., Outten, C. E., Hale, J. \& O'Halloran, T. V. (2000). Transcriptional activation of an Escherichia coli copper efflux regulon by the chromosomal MerR homologue, cueR. J Biol Chem 275, 31024-31029.

Rosenzweig, A. C. (2002). Metallochaperones: bind and deliver. Chem Biol 9, 673-677.

Schelert, J., Dixit, V., Hoang, V., Simbahan, J., Drozda, M. \& Blum, P. (2004). Occurrence and characterization of mercury resistance in the hyperthermophilic archaeon Sulfolobus solfataricus by use of gene disruption. J Bacteriol 186, 427-437.

Stoyanov, J. V., Hobman, J. L. \& Brown, N. L. (2001). CueR (YbbI) of Escherichia coli is a MerR family regulator controlling expression of the copper exporter CopA. Mol Microbiol 39, 502-511.

Strausak, D. \& Solioz, M. (1997). CopY is a copper-inducible repressor of the Enterococcus hirae copper ATPases. J Biol Chem 272, 8932-8936.

Thompson, J. D., Higgins, D. G. \& Gibson, T. J. (1994). CLUSTAL W: improving the sensitivity of progressive multiple sequence alignment through sequence weighting, position-specific gap penalties and weight matrix choice. Nucleic Acids Res 22, 4673-4680.

Tottey, S., Rondet, S. A., Borrelly, G. P., Robinson, P. J., Rich, P. R. \& Robinson, N. J. (2002). A copper metallochaperone for photosynthesis and respiration reveals metal-specific targets, interaction with an importer, and alternative sites for copper acquisition. J Biol Chem 277, 5490-5497.

Walker, J. M., Tsivkovskii, R. \& Lutsenko, S. (2002). Metallochaperone Atoxl transfers copper to the $\mathrm{NH}_{2}$-terminal domain of the Wilson's disease protein and regulates its catalytic activity. J Biol Chem 277, 27953-27959. 